DOI: 10.35784/IAPGOS.734

\title{
LOW COST SOLAR THERMOELECTRIC WATER FLOATING DEVICE TO SUPPLY MEASUREMENT PLATFORM
}

\author{
Andrzej Nowrot ${ }^{1}$, Monika Mikołajczyk ${ }^{2}$, Anna Manowska ${ }^{1}$, Joachim Pielot ${ }^{1}$, Antoni Wojaczek ${ }^{1}$ \\ ${ }^{1}$ Silesian University of Technology, Department of Electrical Engineering and Automation in Industry, Gliwice, Poland, ${ }^{2}$ Famur Institute Ltd, Katowice, Poland \\ Abstract. This work presents the prototype of the solar - thermoelectric device, which can float on water surface. It produces electrical energy as a result \\ of the Seebeck effect in a commercial, low-cost Peltier module. The main application of the device will be an autonomous and a floating measurement \\ platform. An important advantage of the presented solution is the possibility to work alike at day, when a solar light heats the surface of the absorber, and \\ at night, when the different of temperatures between air and water causes the heat flux and in an effect the electricity. The device is capable of working for \\ many cloudy days and also in winter on very short days. The presented device is based on low-cost and widely available components.
}

Keywords: thermoelectric devices, solar power generation, energy conversion

\section{TERMOELEKTRYCZNE URZĄDZENIE SOLARNE DO ZASILANIA PLATFORMY POMIAROWEJ}

Streszczenie. W pracy zaprezentowano prototypowe solarne urzadzenie termoelektryczne plywajace po powierzchni wody. Wytwarza ono w niedrogim, komercyjnym module Peltiera energię elektryczna $w$ wyniku zachodzacego w nim zjawiska Seebecka. Docelowo głównym obszarem aplikacyjnym urządzenia będzie zasilanie autonomicznej, pływającej platformy pomiarowa do monitorowania parametrów środowiskowych. Istotna zaleta przedstawionego rozwiazania jest możliwość pracy zarówno $w$ dzień, gdy światło słoneczne ogrzewa powierzchnię absorbera, jak również w nocy, gdy różnica temperatur między powietrzem a woda powoduje powstawanie strumienia ciepła w module Peltiera. Urządzenie może pracować przez wiele pochmurnych lub krótkich dni, także w zimie. Do konstrukcji układu zastosowano relatywnie tanie i łatwo dostęne w handlu komponenty.

Słowa kluczowe: urządzenie termoelektryczne, solarny generator energii, konwersja energii

\section{Introduction}

The most popular power sources for any mobile measurement platforms and low power consumption portable devices is a photovoltaic cell (PVC). An electrical energy produced in that cell is partially used to supply electronics units and is partially stored in batteries or in supercapacitors (SuperCap). A typical energy efficiency of the photovoltaic cell is about over a dozen percent. A significant constraint of commercial photovoltaic cells is a adaptation to work in the visible region only - it is a consequence that the solar cells are made out of n-type and p-type semiconductor materials. It should be note, in this context, the radiant energy emitted from the Sun, approximately $50 \%$ lies in the infrared region, about $40 \%$ in the visible region and about $10 \%$ in the UV region [7]. Moreover, when the sky is cloudy, the generated electrical power by PVCs decreases a few times to even several dozen times. Exemplary, the typical commercial silicon PVC panel (MN Green Power MWG-10, dimensions of cells area $0.30 \times 0.25 \mathrm{~m})$ generates electrical power about $10 \mathrm{~W}$ at completely clear skies and at sun rays reaching perpendicular to panel's surface. Whereas, exactly the same cell generates power barely about $0.3 \mathrm{~W}$ to $0.6 \mathrm{~W}$ on a cloudy day and less than $0.1 \mathrm{~W}$ on a cloudy and rainy day. All above values of the power were measured at optimal operating point - it means for the load resistor collecting the maximum generated output power. This result may seem surprising, but that is because the human eye has got approximately a logarithmic characteristic of sensitivity and the changes of light intensity seem deceptively small. Moreover, the output voltage of the non loaded photovoltaic panel (open circuit voltage) depends to small extent on a weather. This voltage for the above exemplary photovoltaic panel is equal up to $21.7 \mathrm{~V}$ on a sunny day and about $16 \mathrm{~V}$ on a cloudy day. However, if the panel would be loaded by the resistor (several dozen Ohms), the output voltage will decrease at most down to half on a sunny day and it will drastic decrease (ten or more times) on a cloudy day. So, the output voltage of the non loaded PVC panel is very confusing indicator of its electrical power. Much more practical information of electrical properties of photovoltaic cells are given in the work [8].

Another technical possibility to obtain the electricity from solar energy is an application of a thermoelectric generator (TEG) integrated with a solar absorber and a cooler. In 2003, authors in the paper [13] show a low cost stove-top thermoelectric generator for regions with unreliable electricity supply, which is based on a redesigned commercial Peltier module (TEC - Thermoelectric
Cooler). While a wood is burned in the cooker in order to heat the building or cooking, additional the electricity is produced. Nowadays, important application potential of TEGs is in a field of military [16] and space technology [14]. In the paper [14] authors discuss radioisotope thermoelectric generators (RTGs). They have a very long operating time and have been used in many space missions. Another thermoelements - the TECs are generally used inter alia in portable coolers (in cars) or small fridges, but they may work also in reversible mode - as the thermoelectric generator. Principle of operation of TEC working as TEG and the thermocouple are based on the Seebeck effect and consequently many of their features are very similar. The fundamental difference between them is maximal operating temperature and maximal generated electrical power. Due to TEC contains the ptype and the n-type semiconductors, it can work typically in temperature range up to $130-150^{\circ} \mathrm{C}$ only, but it can produce useful amounts of electrical energy. The thermocouple contains dissimilar electrical conductors (metals) and can work even in temperature of the order of $1000-2000^{\circ} \mathrm{C}$, but unfortunately it produces electrical power of order of microwatts. The thermoelectric generator based on Peltier module could be very useful to small-scale an electrical energy produce. The paper [4] includes a review of development of stove-powered TEGs in the last two decades. In recent years, there are new designs and trends of solar thermoelectric generators in the word-wide literature. Generally, in the solar TEGs, the upper surface of the device is heated by the solar radiation and it makes the heat flux which drifts down through the thermoelectric element to the cooler (e.g. dived in water). A typical efficiency of the conversion the heat energy into the electrical energy (while the Seebeck effect) is equal up to a few percents only, but in contrast to photovoltaic cells, a solar absorber (upper surface of the device) is able to absorb light in wide spectra cover the visible and the most of the infrared region - it depends on the spectral properties of the absorber. In this research paper, we propose the new approach in the solar supply the measurement platforms. It is based on solar thermoelectric unit within a low - cost and commonly used Peltier module associated with the dedicated electronics circuit providing the automatic settings the optimal operation point of the system (maximal generated electrical power). A very important advantage of the presented in this paper device is the possibility of operating without the solar light (e.g. at night) or at the very cloudy day. In this "dark mode", the heat flux in the thermoelectric module is caused by the difference of temperature between air and water, but it does not matter if the air is warmer than the water or vice versa. It is a matter of an existence of different temperatures between 
them only. The device produces electricity also while a hard winter, when the air temperature is down to $-30^{\circ} \mathrm{C}$ and the temperature of salt water or untreated water covers the range of $-2^{\circ} \mathrm{C}$ to $0^{\circ} \mathrm{C}$. We think, it is also possible to work the device, when the cooler radiators are immersed in ice (e.g. in a frozen lake), but we have never tested this case. In the work [9] authors propose an interesting construction of the solar annular thermoelectric generator (SATEG). It provides significantly higher efficiency in compare to so far used flat thermoelectric modules but it simultaneously increases the price of the device and it complicates fabrication process. Authors in the paper [17] show the electric power generation from solar pond using combined thermosyphon and thermoelectric modules. Unfortunately, it is a stationary system and unsuitable for any moveable platform. In conclude, the features of that generator are significantly different in compare to photovoltaic cells. The measurement platform and the proposed for it the low-cost solar thermoelectric water floating device will operate autonomously for a long period of time in the varied weather conditions and seasons, while natural disasters, flood etc. Therefore, the platform needs a reliable power supply based on the shockproof TEG or the hybrid power source based on TEG with the photovoltaic cell. The application the photovoltaic cell only is definitely insufficient to meet the assumed requirements. It is very important, e.g. in the Central Europe, where in the winter the day lasts only a few hours.

\section{Proposed device}

The illustration in Fig. 1 shows schematic of the mechanical construction of the proposed thermoelectric device. The sunlight passes through the glass cover and next is absorbed in the absorber plane. A commonly use a heat-proof clear glass dish was applied as the cover glass. This $2.5 \mathrm{~mm}$ thickness glass very good transmits a solar radiation in the visible and the infrared range It stops the heated air and prevents heat exchange to outside as a result of gas convection. The absorber has got a shape of a flat plate with dimensions of total diameter $256 \mathrm{~mm}$, useful diameter $244 \mathrm{~mm}$ (covered by the glass cover) and thickness $4 \mathrm{~mm}$. It is made of aluminum. The upper absorber surface was treated to one of the galvanization methods - anodizing with blackening. In result, this surface is matt dark and very good absorbs light. The anodized coating is resistant to high temperature and temperature changes in the wide range. That is impossible to obtain using a paint dedicated to aluminum - guaranteed maximum exploitation temperature for popular black paints is up to $50^{\circ} \mathrm{C}$. The glass cover is mounted in a shallow hollow ring in the absorber's surface (located close to the outside edge of the absorber plane). The air under the glass cover is dehumidified before its closing.

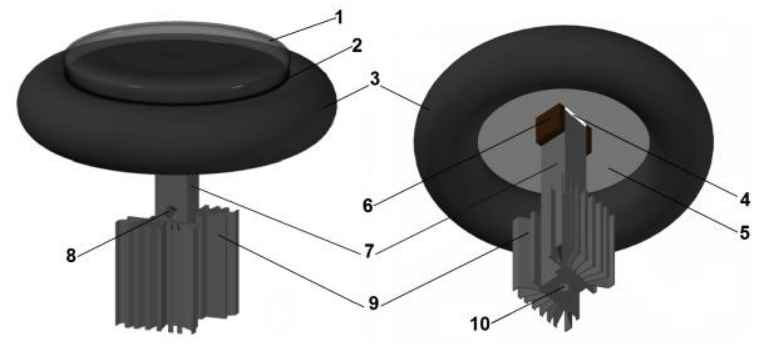

Fig. 1. Schematic of the mechanical construction of the proposed thermoelectric device. 1 -glass cover, 2 - circular absorber plane situated under the glass cover, 3 -buoyancy tube, 4 -Peltier module, 5 -absorber plate bottom covered with the styrofoam isolation layer, 6 - one of the two bakelite connector blocks, 7 -aluminum flat square bar profile, 8 -one of the two side holes to the upper end of the inside channel, 9 -cooler radiators, 10 - bottom hole to inside channel

Directly under the bottom of the absorber plane is centrally situated the Peltier module. We applied a popular and general use Peltier module TEC1-12706 Hebei I.T. Shanghai Co., Ltd. It has got dimensions of $40 \times 40 \times 3.9 \mathrm{~mm}$ and maximal operating current of $6.4 \mathrm{~A}$. The module can work in the range of temperature up to $138^{\circ} \mathrm{C}$ only, but this value is absolutely enough to operate in the presented device. The carried out measurement showed the absorber plane surface heats maximally up to about $88^{\circ} \mathrm{C}$ (conditions: cover glass put on, completely clear sky, the absorber sets perpendicularly to the sun ray, air temperature $33^{\circ} \mathrm{C}$ ). Output wires of the TEC are connect to dedicated electronics unit (it is not shown in Fig. 1). The rest part of the bottom surface of the absorber plane is covered with $2 \mathrm{~mm}$ styrofoam layer. Next, under the TEC is mounted to the aluminum flat square bar profile rectangular block (marked as 7 in Fig. 1). The profile has got dimensions of $40 \times 40 \times 300 \mathrm{~mm}$ and transfers the heat flux from TEC to radiators. There was hollowed out the round channel along the length of the profile. The channel is located between the half of the profile length (marked as 8 in Fig. 1) and the profile bottom (marked as 10 in Fig. 1). It improves water circulation and the cooling process. The absorber plane was mounted to the bar profile through the two flat bakelite blocks (marked as 6 in Fig. 1). The Peltier module is pressed against between them. Due to a bakelite is electrical non conductivity, heat-resistant and non fragile in wide temperature range it was elected to connect of them. Its thermal conductivity is only about $0.2 \mathrm{~W} /(\mathrm{m} \cdot \mathrm{K})$ [9]. The bakelite blocks were threaded and the assembly elements were connected with each other by steel screw. Additional, to reduce the heat resistance in joints absorber plane surface - Peltier module - flat aluminum profile - radiators, the silicone thermal paste was used. A buoyancy tube was applied under the styrofoam layer and the absorber plain. The images in Fig. 2 show the thermoelectric device prototype while "dry testes" - at the beginning experiments without the cover glass and the buoyancy tube.

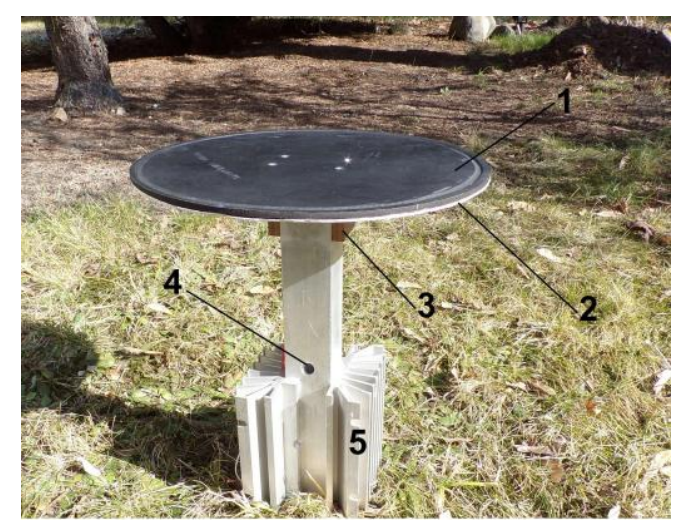

Fig. 2. Thermoelectric device prototype without the cover glass and the buoyancy tube. 1 - circular absorber plane, 2 - styrofoam layer (thermal isolation), 3 -bakelite connectors, 4 -flat aluminum profile and the upper hole of the internal channel, 5 - radiators

Despite the glass cover and a tank with water to cooling the radiators are not applied in the simplest configuration (Fig. 2), the dark absorber surface is quickly heated in a sunshine and an electrical energy is produced. After 3 minutes exposition for sunrays (the case seen in Fig. 2), the different of temperatures between central point on absorber surface and the aluminum flat profile (measured $5 \mathrm{~cm}$ below the TEC) increases to about $16^{\circ} \mathrm{C}$. The Peltier module were connected to the external dedicated electronics unit. The unit contains the switching voltage regulators and it is controlled by the main platform's computer. We assume that it will be closed in the waterproof IP68 housing. At the moment, the first version of the electronics unit's prototype has been constructed. One of the most important function of the unit is providing the optimal operating point in the thermoelectric generator. It is needed, because for each temperature different it is possible to determine the electric power vs. load resistance characteristic. Voltage converting and impedance matching are not a simple issue as it might seem. A single Peltier module, while working as a thermoelectric generator, generally provides voltage in range of $0.3 \mathrm{~V}$ to $1 \mathrm{~V}$. That is too low to correct operating of any standard and commercial known voltage converter. For example the MCP1623 compact DC-DC converter (Microchip Technology Inc.) has got start-up voltage of $0.65 \mathrm{~V}$ for output voltage of $3.3 \mathrm{~V}$ and after start, it can operate with minimal input 
voltage of $0.35 \mathrm{~V}$. Unfortunately these low voltages are allow for output current of $1 \mathrm{~mA}$ only - it is absolutely not enough current to supply the measurement platform. To obtain higher output current it is necessary significantly higher input voltage $-1.2 \mathrm{~V}$ for current $50 \mathrm{~mA}$. The application of the MCP1623 requires only five small external electronics components and it probably operates at the lowest input voltage among all boost integrated converters. In conclude, commercial DC-DC converters are not appropriate to work with single module Peltier module working as TEG. Furthermore, above converters do not adapt theirs input resistance to obtain the maximal electrical power in TEG. In the paper [15] authors discuss a dedicated voltage converter maximum power point tracker for thermoelectric generators. That boost converter is much more advanced. It contains a discrete MOSFET power transistor, which is driven by PWM and PI controller and the applied algorithm allows to keep maximum generated power for different temperature differences. Whereas our device is even more demanding. If the absorber plane temperature is less than temperature of the flat bar profile and radiators - sometimes that is possible in the winter, then output voltage polarity of the Peltier module is inverted. Moreover, TEGs exhibit dynamic properties related to the intensity of temperature changes, what is often ignored in many considers, and these properties influence to maximum generated power. Dynamic characteristics of TEGs are thoroughly showed in the paper [10]. In view of the above factors, works on constructing the final version of the electronics unit are ongoing and will be considered apart in another paper. An important advantage of the device is low total cost of its constructing. Final cost of the device prototype consists of the cost of materials and labor. Price of aluminum components (a profile bar, a think block and radiators) in Poland is equal about 30 euros. The applied TEC module costs about 8 euros. Price of other components (screws, a buoyancy tube, silicone thermal paste) is up to 10 euros. All above prices include taxes. The cost of machining aluminum components on a lathe and assembling the device is equal up to 8 man-hours. Of course the above estimates do not take into account the long time devoted to the design of the device, its examination and improvement.

\section{Results and discussion}

The proposed thermoelectric device was tested in various conditions. The image in Fig. 3 shows thermoelectric device prototype while floating on pond water surface on sunny September day in south west Poland. Its total mass is about equal to $3.9 \mathrm{~kg}$. The volume of submerged elements (part of the buoyancy tube, radiators and part of the aluminum flat bar profile) is about equal to $5 \cdot 10^{-3} \mathrm{~m}^{3}$ and that gives buoyancy force about $50 \mathrm{~N}$. Thereby the proposed device is able to float on water surface. As a buoyancy tube we tested a moped inner tube and a lifebuoy ring.

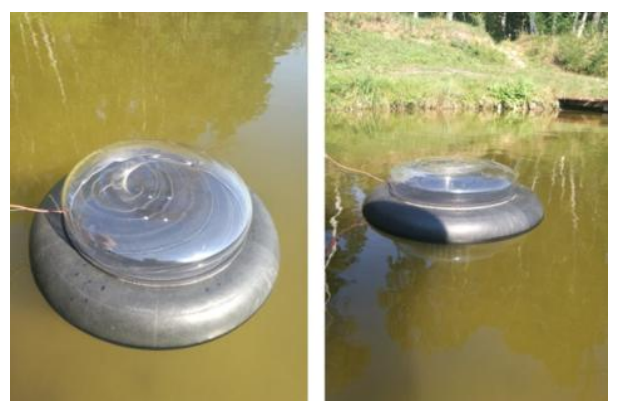

Fig. 3. Thermoelectric device prototype at the beginning testes while floating on water surface

The temperature difference between the central point on the absorber surface and the aluminum flat bar was measured $(3 \mathrm{~cm}$ below the Peltier module on flat bar surface). Two temperature measurement methods were used. The first one was a contact method with two DS18B20 programmable resolution digital thermometer - small integral circuits (products of Dallas Semiconductor). In that application, a digital signal from the thermometer to Arduino UNO microcontroller board was transmitted, and next via USB to a laptop. The second method was a non-contact with the Flir i7 infrared camera. Unfortunately, the last method is more complicated, because needs to multiple and quick taking off the glass cover to correct measure the temperature of the absorber surface. However, after calibrating the IR camera, both above methods have given similar results. For each temperature difference, the current - voltage characteristics were investigated and then, on their basis, the maximum electrical power was determined. Fig. 4 shows an exemplary characteristic for temperature deference of $17^{\circ} \mathrm{C}$

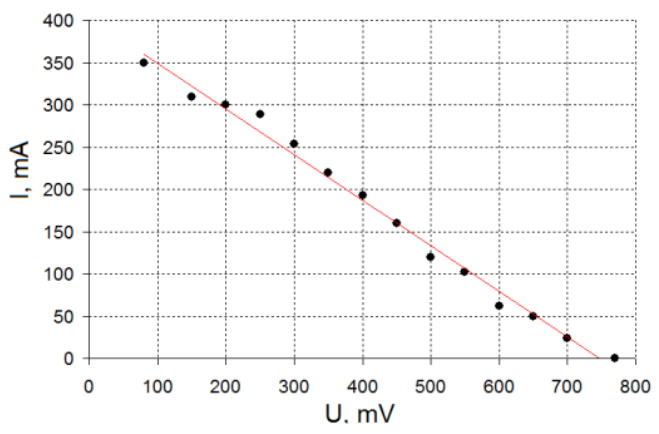

Fig. 4. Exemplary current-voltage characteristic of the Peltier module in the proposed device for temperature deference of $17^{\circ} \mathrm{C}$ (between the absorber surface and the aluminum bar profile)

To obtain the characteristics, TEC's terminals are connected directly to a voltmeter (input resistance $10 \mathrm{M} \Omega$ ), which is parallel connected to the circuit consisting of a ammeter in a serial connection with a slide variable resistor - load resistor. The above meters configuration makes that the internal ammeter resistance does not influence to the voltage indication. If the measuring points are arranged approximately along a straight line just like in Fig. 4, then the Peltier module (which working as a thermoelectric generator) could be considered as the Thevenin equivalent circuit connected to a load resistor - Fig. 5. An idea of the Thevenin equivalent circuit have been clearly explained in the book [1]. The voltage UTEG is the thermoelectric force of that TEG and it is the voltage of non loaded TEC (when RLOAD $\rightarrow \infty$ ). The resistance RINT is mainly related to the p-type and n-type semiconductors resistance inside the structure of the module. For commercially available TEG devices, the value of RINT changes by approximately $0.3-0.75 \%$ per $1{ }^{\circ} \mathrm{C}$ increase of the average temperature between the hot and cold sides [15]. The linear fit in Fig. 4 is given by the Eq. (1). The absolute value of the "a" directional coefficient represents inverse of an internal resistance RINT in the Thevenin model (Eq. (2)) and the coefficient " $b$ " represent a short circuit current. The same structure of TEG as in Fig. 5 was proposed by the authors in the works $[2,3,15]$

$$
I=a U+b
$$

where: $\mathrm{U}$ - voltage, I - current, coefficients determined for the fit in Fig. $4\left(\mathrm{~T}=\Delta 17^{\circ} \mathrm{C}\right) \mathrm{a}=-0.54(2) \Omega^{-1}, \mathrm{~b}=0.403(7) \mathrm{A}$

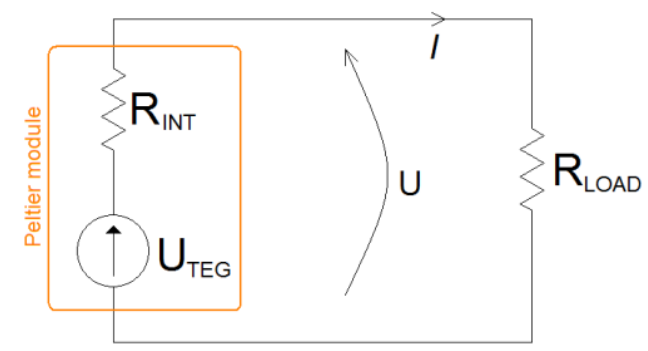

Fig. 5. Peltier module (working as a TEG) represented by the Thevenin equivalen circuit is connected to load resistance UTEG-thermoelectric force-voltage of the non loaded Peltier module, RINT - internal resistance of the Peltier module 


$$
R_{I N T}=\frac{1}{|a|}
$$

Typical value of the $R_{I N T}$ resistance is of the order of several Ohms. Therefore, an electrical power is the product of voltage and current, having Eq. (1), the generated power can be written by Eqs. (3) - (4). The maximal power can be calculated by equating the derivative of the expression to zero - Eq. (5). In effect the maximal power is given by Eq. (6) - it corresponds to the situation in the schematic in Fig. 5 when the load resistance $R_{L O A D}$ is the same as the internal resistance RINT.

$$
\begin{gathered}
P=U I \\
P=U(a U+b) \\
\frac{\partial P}{\partial U}=2 a U+b=0 \\
P_{\max }=-\frac{b^{2}}{4 a}
\end{gathered}
$$

where: $P$ - electrical power, $P_{\max }-$ maximal electrical power, the factor " $\mathrm{a}$ " is always negative (see Fig. 4 and Eq. (1)).

The plot in Fig. 6 shows maximal electrical power generated by the thermoelectric device as a function of temperature difference. The experimental points are well approximated by mathematical model presented in Eq. (7).

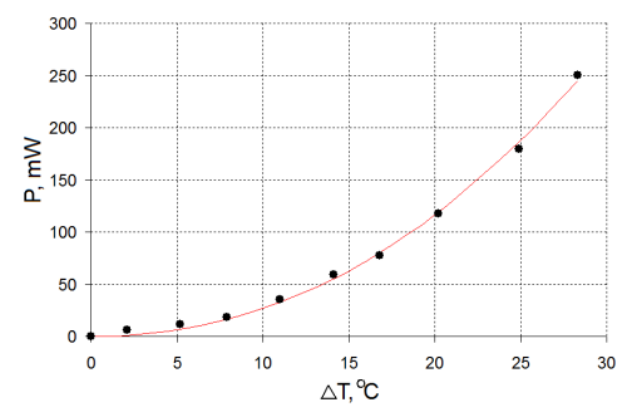

Fig. 6. Electrical power generated by the thermoelectric device vs. temperature difference between the central point on the absorber surface and the aluminum flat bar. As a temperature sensors were applied two DS18B20 digital thermometers

$$
P=k \cdot(\Delta T)^{n}
$$

where: $P$ - electrical power in $\mathrm{mW}, \Delta T$ - temperature difference in ${ }^{\circ} \mathrm{C}, k$ and $n$ - equation coefficients: $k=0.19(4) ; n=2.14(7)$.

The value of the factor " $\mathrm{n}$ " in the Eq. (7) indicates that generated electrical power is approximately proportional to the square of the temperature difference. The authors in the paper [5] a very similar experimental results have obtained. In the works [3, 15] have been theoretically demonstrated for the simplified TEG model, that the generated power depends on the square of the temperature difference. A precision theoretical determination of the power - temperature difference characteristic does not make sense in this case, because in practice an electrical power depends on many factors. In materials for TECs, the Fermi level dependence on temperature, electrons and holes diffusion and effects of electron-phonon interaction on transport are observed. They give a complicated mathematical model and moreover many parameters of general use TECs are unknown. Above processes in TEG have been thoroughly discussed in the book [11]. An experimentally determination of the power - temperature difference characteristic (just like in Fig. 6) is more beneficial in practice. The device generates electrical power according to Eq. (7) regardless of how the temperature difference is obtained - by heating the absorber surface with sun rays or by the heat exchange between an air and the absorber profile. It is it's a very important feature. The investigations conducted on January evening (during winter in Poland) showed that, if the air temperature is $-3.1^{\circ} \mathrm{C}$ and temperature of water in the pond is $5.5^{\circ} \mathrm{C}$, then the device produced electrical power of about $15.5 \mathrm{~mW}$, while for exactly the same conditions the photovoltaic cell (surface dimensions $0.30 \times 0.25 \mathrm{~m}$ ) generated power less than $1.9 \mathrm{~mW}$. Whereas, if the absorber plane is heated by sunrays, its temperature is not the same in any its point. Therefore the Peltier module (situated under the central area of absorber plane) causes heat transfer down to flat bar profile and radiators, measurements with infrared camera were done. An exemplary surface temperature distribution of the absorber upper plane (while the maximum electrical power is generated) is shown in thermograph in Fig. 7. That photo was taken immediately after take off the glass cover (a glass layer misrepresents a true temperature of the covered surface in thermovision). Its central area is clearly cooler $\left(53^{\circ} \mathrm{C}\right)$ in compare to other area - up to $58^{\circ} \mathrm{C}$ near to edge of the absorber plane. The thermograph below (Fig. 7) lets to determine the surface temperature distribution as a function of distance from its center point - Fig. 8 .

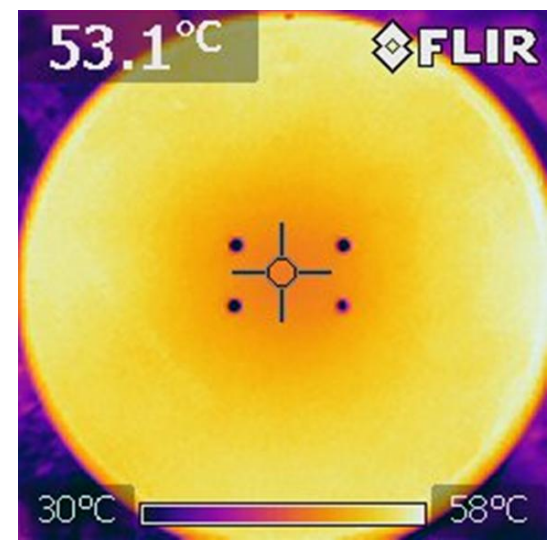

Fig. 7. Exemplary thermograph of the absorber plane surface (surface temperature distribution)

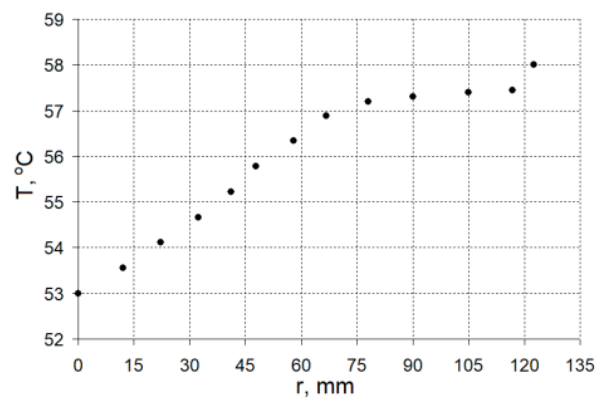

Fig. 8. Surface temperature distribution for the thermograph in Fig. 7 as a function of distance from the absorber center point

Analysis of the results in Fig. 7 and Fig. 8 leads to the conclusion that the main area of heat collection by the Peltier module is located for range $0<\mathrm{r}<65 \mathrm{~mm}$ - it accounts for about $28 \%$ of the total surface. The hottest place for radius $122 \mathrm{~mm}<\mathrm{r}<126 \mathrm{~mm}$ corresponds to the shallow hollow ring in the absorber surface (is dedicated to glass cover). Ignoring that ring, in the range $65 \mathrm{~mm}<\mathrm{r}<122 \mathrm{~mm}$ the temperature changes are less than $1.2^{\circ} \mathrm{C}$.

\section{Conclusions}

This paper presents the prototype of the floating solar thermoelectric device dedicated to an autonomous measurements platform. In the final construction, the device and the platform will become integrated and will be able to float on water surface. This device generates electrical energy regardless of how the temperature difference is obtained, for example on winter evening while the cooler is warmer than the absorber profile and the heat between air (the environment) and the absorber profile is exchanged. In conclusion, the presented device can work at day, when a solar light heats the surface of the absorber, and at night, when the difference of temperatures arises as a result of the air absorber heat exchange. It should be noted that, the investigation of single Peltier module is not the same that the investigation of thermoelectric generator based on this module. The conducted 
researches have shown that the electrical power could be greater more over three times for the same absorber surface in the device. While the Peltier module generates electric current and heat is collected from the absorber profile to the cooler, the module influences noticeably only for about $28 \%$ of the total absorber surface. In the next step, we are going to improve our prototype device and to increase the numbers of TECs to three and thereby the all absorber surface will be efficiently used. In that case, the maximum generated power will be increased to $750 \mathrm{~mW}$. To provide maximum power for each temperature difference, it is needed to adjust and to keep the optimal operating point in the current - voltage characteristic. It will realize in the dedicated voltage converter which will automatically adjust its input impedance. The proposed floating solar thermoelectric device is not very complicated to construct and because it is based on commercial TEC, it is inexpensive - this is an important advantage. Authors in the work [12] clearly, experimentally demonstrated in the temperature range from $0^{\circ} \mathrm{C}$ to $100^{\circ} \mathrm{C}$, that the efficiency of TEC (working as a thermoelectric generator) is very similar to much more expensive (about 15 or more times) commercial thermoelectric power generators. Moreover, in this comparison, for temperatures between $20^{\circ} \mathrm{C}$ and $40^{\circ} \mathrm{C}$, the Peltier module is even a little bit more efficient. The main inconvenience of TEC is not high maximum operating temperature (about $140^{\circ} \mathrm{C}$ only), but this is absolutely not a problem, because the presented device always works for temperatures below $100^{\circ} \mathrm{C}$. Finally, the optimal solution seems to be the simultaneous use of the presented device and a photovoltaic cell. When photovoltaic cells are unable to operate (e.g. on very cloudy days or on short days), the proposed device will provide electrical power to the autonomous measurement platform for many hours or days. On sunny days, the surplus of produced energy can be stored in batteries.

\section{References}

[1] Agarwal A., Lang J. H.: Foundations of Analog and Digital Electronic Circuits. Morgan Kaufmann Publishers (Elsevier), San Francisco 2005.

[2] Cao Z., Koukharenko E., Tudor M. J., Torah R. N., Beeby S. P.: Flexible screen printed thermoelectric generator with enhanced processes and materials. Sensors and Actuators A: Physical 238/2016, 196-206, [DOI: 10.1016/j.sna.2015.12.016].

[3] Dunham M. T., Barako M. T., LeBlanc S., Asheghi M., Chen B., Goodson K. E.: Power density optimization for micro thermoelectric generators. Energy 93/2015, 2006-2017, [DOI: 10.1016/j.energy.2015.10.032].

[4] Gao H. B., Huang G. H., Li H. J., Qu Z. G., Zhang Y. J.: Development of stovepowered thermoelectric generators: A review. Applied Thermal Engineering 96/2016, 297-310, [DOI: 10.1016/j.applthermaleng.2015.11.032].

[5] Hasani M., Rahbar N.: Application of thermoelectric cooler as a power generator in waste heat recovery from a PEM fuel cell - An experimental study. International Journal of Hydrogen Energy 40/2015, 15040-15051, [DOI: 10.1016/j.ijhydene.2015.09.023].

[6] Laughton M. A., Say M. G.: Electrical Engineer's Reference Book - Fourteenth edition. Butterworth International Edition 1990.

[7] Liou K. N. (Ed.): An Introduction to Atmospheric Radiation. International Geophysics - Chapter 2: Solar Radiation at the Top of the Atmosphere. International Geophysics 84/2002, 37-64, [DOI: 10.1016/S0074-6142(02)80017-1]

[8] Luque A., Hegedus S.: Handbook of Photovoltaic Science and Engineering (2nd edition), Wiley \& Sons, 2010

[9] Manikandan S., Kaushik S.C.: Energy and exergy analysis of solar heat pipe based annular thermoelectric generator system. Solar Energy 135/2016, 569-557, [DOI: 10.1016/j.solener.2016.06.031].

[10] Merienne R., Lynn J., McSweeney E., O'Shaughnessy S. M.: Thermal cycling of thermoelectric generators: The effect of heating rate. Applied Energy 237/2019, 671-681, [DOI: 10.1016/j.apenergy.2019.01.041]

[11] Morelli D. T.: Thermoelectric Materials. In: Kasap S., Capper P. (eds) Springer Handbook of Electronic and Photonic Materials. Springer Handbooks. Springer, Cham.

[12] Nesarajah M., Frey G.: Thermoelectric Power Generation: Peltier Element versus Thermoelectric Generator (TEC vs. TEG). Proceedings of the 42nd Annual Conference of IEEE Industrial Electronics Society (IECON2016) 2016, 4252-4257, [DOI: 10.1109/IECON.2016.7793029].

[13] Nuwayhid R. Y., Rowe D. M., Min G.: Low cost stove-top thermoelectric generator for regions with unreliable electricity supply. Renewable Energy 28/2003, 205-222, [DOI 10.1016/S0960-1481(02)00024-1].

[14] O’Brien R. C., Ambrosi R. M., Bannister N. P., Howe S. D., Atkinson H. V.: Safe radioisotope thermoelectric generators and heat sources for space applications. Journal of Nuclear Materials 377/2008, 506-521, [DOI: 10.1016/j.jnucmat.2008.04.009].
[15] Paraskevas A., Koutroulis E.: A simple maximum power point tracker for thermoelectric generators. Energy Conversion and Management 108/2016, 355-365, [DOI: 10.1016/j.enconman.2015.11.027].

[16] Saqr K. M., Musa M. N.: Critical review of thermoelectrics in modern power generation applications. Thermal Science 13(3), 2009, 165-174, [DOI: 10.2298/TSCI0903165S]

[17] Singh R., Tundee S., Akbarzadeh A.: Electric power generation from solar pond using combined thermosyphon and thermoelectric modules. Solar Energy 85/2011, 371-378, [DOI: 10.1016/j.solener.2010.11.012].

\section{Ph.D. Eng. Andrzej Nowrot \\ e-mail: andrzej.nowrot@polsl.p}

Andrzej Nowrot received M.Sc. in Automatic Control and Robotics at the Faculty of Automatic Control, Electronics and Computer Science at the Silesian University of Technology (SUT), Poland, in 2003, and the Ph.D. in Physics from the University of Silesia, Poland, in 2010. Since 2004 he has cooperated with the Institute of Physics SUT. Since 2015 he has been employed at the Department of Electrical Engineering and Automation in Industry SUT. His research interests are sensors and non-electrical quantity measurements, nanomaterials applications in detectors and a renewable energy

ORCID ID: 0000-0001-8977-0316

M.Sc. Eng. Monika Mikołajczyk

e-mail: mmikolajczyk@ famur.com.pl

Monika Mikołajczyk received M.Sc. in the Faculty of Mining, Safety Engineering and Industrial Automation at the Silesian University of Technology in the field of Electrical Engineering and Automation in Mining. Currently, he is involved in the design and programming of embedded and prototype systems at Famur Institute Ltd. in Katowice. The area of scientific interest includes conversion of thermal and solar energy into electricity and guaranteed power supply systems.

ORCID ID: 0000-0002-2843-5570

\section{Ph.D. Eng. Anna Manowska}

e-mail: anna.manowska@polsl.pl

Anna Manowska is an adjunct at the Department of Electrical Engineering and Industrial Automation at the Silesian University of Technology and a member of the Mining Economics Section of the Polish Academy of Sciences. She is the author of about 80 scientific articles. The area of scientific interest concerns the energy market analysis using advanced IT tools with particular emphasis on the role of hard coal and renewable energy.

ORCID ID: 0000-0001-9300-215X

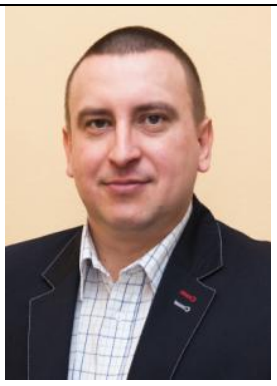

\section{Prof. Joachim Pielot}

e-mail: joachim.pielot@polsl.pl

Joachim Pielot is the head of the Department of Electrical Engineering and Industrial Automation of the Silesian University of Technology and a member of the Association of Polish Electrical Engineers. He is the author of about 130 scientific articles. The area of scientific interest concerns the control of production processes, in particular the optimization of production in technological systems for mineral processing, metrology of electrical and non-electrical quantities, as well as analog and digital signal processing ORCID ID: 0000-0001-7679-2049

\section{Prof. Antoni Wojaczek
e-mail: antoni.wojaczek@ polsl.pl}

Antoni Wojaczek is a professor at the Department of Electrical Engineering and Industrial Automation of the Silesian University of Technology and an expert in telecommunications specialization covering design and execution without restrictions in the field of telecommunications. He is the author of about 180 scientific articles. The area of scientific interest concerns telecommunications, especially for mining and electromagnetic compatibility in mining. ORCID ID: 0000-0002-2256-0661

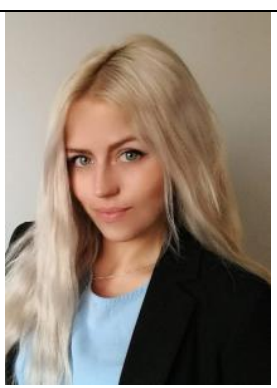

otrzymano/received: 01.11.2019
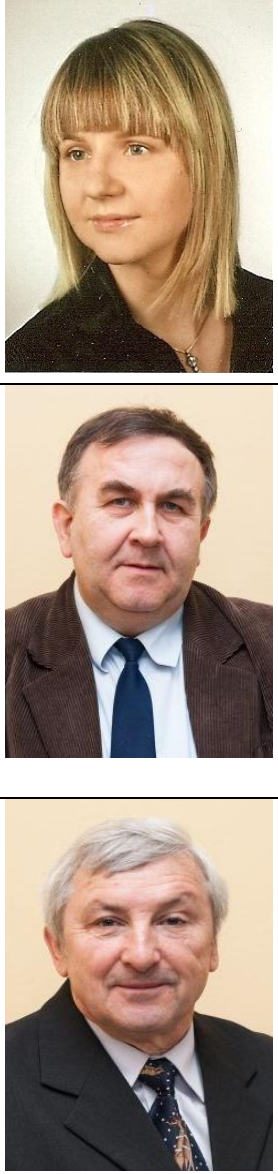